\title{
Antibacterial Efficacy of Aqueous Plant Extracts against Storage Soft Rot of Potato Caused by Erwinia carotovora
}

\author{
H.S. Viswanath, K.A. Bhat" ${ }^{*}$ N.A. Bhat, T.A. Wani and Mohammad Najeeb Mughal \\ Division of Plant Pathology, Faculty of Agriculture, Wadura campus, Sher-e-Kashmir \\ University of Agricultural Sciences and Technology, Kashmir-193201, India \\ *Corresponding author
}

\begin{abstract}
A B S T R A C T
Bacterial soft rot is one of the most common diseases of vegetables including potato which is found both in field and storage. Although, various micro-organisms are responsible for the soft rot disease in potato but Erwinia carotovora is mostly responsible for this disease. Use of chemical antibiotics on stored products can lead to the development of multidrug resistance in various human pathogenic bacteria causing severe health complications. In this present study, 13 aqueous plant extracts were evaluated against soft rot causing pathogen, Erwinia carotovora in-vitro. Among them, best control with highest mean diameter zone of inhibition of $11.7 \mathrm{~mm}$ against the test bacterium was shown by Datura stramonium followed by Ficuscarica with mean diameter zone of $9.5 \mathrm{~mm}$. Other extracts with decreasing order of efficacy were Polygonum hydropiper (leaves), Populus alba (leaves), Trigonella foenum-graecum (seeds), Azadirachta indica (leaves), Curcuma longa (Rhizome) and Salix alba (green bark). Extracts of Cannabis sativa (leaves), Zingiber officinale (rhizome), Juglans regia (leaves) and Conyza canadensis (leaves) showed moderate efficacy against the test bacterium and least zone of inhibition was exhibited by Anthemis cotula (leaves). Standard check (streptomycin @ 150ppm) gave mean diameter zone of inhibition of $15.3 \mathrm{~mm}$. Three extracts which proved highly effective in-vitro were evaluated on potato tubers against the disease at different inoculation times viz 12 hours prior to, simultaneously and 12 hours after the inoculation of the pathogen. Among them, highest control was shown by Datura stramonium when applied simultaneously with the pathogen inoculation, exhibiting disease severity of $24 \%$ and $25.6 \%$, when applied 12 hours prior to the inoculation of the pathogen, followed by Ficuscarica when applied 12 hours prior to inoculation of the pathogen with severity of $31.2 \%$ after 6 days of storage.
\end{abstract}

Keywords

Aqueous plant extracts, Erwinia carotovora, Postharvest soft rot, Potato

Article Info

Accepted:

20 December 2017 Available Online: 10 January 2018

\section{Introduction}

Potato (Solanum tuberosum L.) is one of the most important food crops worldwide and represents a valuable source of nutrients in a balanced diet. In terms of human consumption, the potato is the third most important food crop in the world, following only rice and wheat Czajkowski (2011). Postharvest soft rot is one of the destructive diseases of vegetables including potato. It occurs worldwide wherever vegetables and ornamentals having fleshy storage tissues are found. The disease can be found on crops in the field, in transit and in storage or during marketing. Soft-rot causes greater total loss of 
produce than any other bacterial disease causing severe losses varying between 15$30 \%$ of the harvested crop Agrios (2007: Bhat et al., 2010). Chemical control of the disease has not been successful even in the developed countries, besides the use of antibiotics is not considered safe in view of human health considerations besides Indiscriminate use of chemical antibiotics to control various postharvest spoilage bacteria of stored vegetables causes health hazards by developing resistance to human pathogenic bacteria to those antibiotics. Considering the destructive nature of the disease, adverse and alarming effects of chemical antibiotics, and this study was undertaken to find out alternative and nontoxic botanical extracts to control the soft rot causing bacterial pathogen(s) of potatoes in storage.

\section{Materials and Methods}

\section{Collection of plant specimens}

Extracts of thirteen plant species were used during the present studies. Out of these nine species were native to Kashmir valley, while parts of four species used were brought from other regions.

Plant species were identified by Division of Agronomy, Faculty of Agriculture, Sher-ekashmir University of Agricultural Sciences and Technology. List of plants and their parts used are as under:

\section{Preparation of aqueous plant extracts}

Collected plant material was shade dried and grinded into fine powder in an electrical blender. $10 \%$ extract was prepared by mixing $10 \mathrm{~g}$ of powder in $100 \mathrm{ml}$ water by boiling at $100^{\circ} \mathrm{c}$ on water bath for 20 minutes.

Resultant suspensions obtained were filtered through Whatmann filter paper 1 and the concentrated filtrate material stored in glass bottles at $4^{\circ} \mathrm{C}$ in refrigerator for further studies.

\section{Isolation of the causal pathogen}

Diseased vegetables and potato tubers showing typical soft rot symptoms were collected from the local markets from Kashmir valley. Collected samples were surface sterilized with $0.1 \%$ sodium hypochlorite solution and the infected tissue was macerated in sterile water to make a bacterial suspension.

A drop of resultant suspension was spread on Crystal violet pectate, a semi selective medium (CVP). The type of colonies which upon flooding with $1 \%$ hexadecyltrimethyl ammonium bromide(precipitant solution) formed halo zones around them on Crystal violet pectate medium (CVP) were selected for subculturing on nutrient agar and were tested for pathogenicity.

\section{Pathogenicity test by potato slice assay}

Potato tubers were first surface sterilized with sodium hypochlorite solution $(0.5 \%)$ and cut into slices $(1.0 \mathrm{~cm}$ in thickness) with sterile blade. These Slices were inoculated by smearing a loop full of bacteria at the centre, on the surface of healthy tuber slice. The inoculated tuber slices were incubated for 24$48 \mathrm{~h}$ at $28 \pm 2^{\circ} \mathrm{C}$ in Petri plates having sterile filter paper at the bottom of petri plate soaked in $5 \mathrm{ml}$ of sterile water, kept in such a way that the tuber slices should not come in direct contact with the water by placing a glass slide at the bottom of the slice. Tuber slice inoculated with sterile water in one petri plate was kept as control. Softening of the inoculated tuber slices was taken as a positive reaction. From the softened/macerated slice tissue, bacteria was re-isolated and compared with the original isolate of inoculated pathogen (Shashirekha et al., 1987). 
In-vitro screening of antibacterial activity of plant extracts

Nutrient agar medium was prepared. About $15 \mathrm{ml}$ of nutrient agar medium was poured in sterile $10 \mathrm{~cm}$ Petri plates and was allowed to solidify and then 24hour old bacterial culture was taken and mixed with water to make a bacterial suspension, from which $0.5 \mathrm{ml}$ of the bacterial inoculum containing $1 \times 10^{8} \mathrm{cfu} / \mathrm{ml}$ was flooded on the surface of nutrient agar plates and was spread all over by glass spreader. Subsequently, sterile filter paper discs $(6 \mathrm{~mm}$ diameter) impregnated with the test extracts by dipping in plant extract were placed on the surface of the agar at equidistant points using sterile forceps. Plates were incubated at $30^{\circ} \mathrm{c}$ for 24 hours. Antibacterial activity was evaluated by measuring the diameter of the zone of inhibition to the nearest millimetre using ruler. Three discs (comprising of three replications) were kept in each petri plate. Discs saturated with sterile water and antibiotic (Streptomycin @ $150 \mathrm{ppm})$ were kept as negative and positive controls respectively (Las llagas et al., 2014) (Fig. 2).

\section{Screening of effective plant extracts against the disease on stored potato tubers}

Plant extracts which proved best in vitro were used for the treatment on stored potato tubers and applied at different times viz. 12 hours prior to the inoculation of the pathogen, simultaneously with the inoculation of the pathogen and 12 hours after the inoculation of the pathogen. Fresh potato tubers were surface sterilized by dipping in $0.1 \%$ solution of sodium hypochlorite followed by serial washings with sterile water and then dried under the hood of laminar air flow. One set of potato tubers was given 30 pinpricks and dipped in uniform suspensions of different plant extracts for 10 minutes and 12 hours afterwards inoculated with the pathogen by swabbing the bacterial suspension on them. In the second set of tubers, after giving the pinpricks, application of plant extracts was done simultaneously. In third case, the pinpricked tubers were first inoculated by the pathogen by swabbing bacterial suspension on them and 12 hours afterwards they were treated with plant extracts for 10 minutes.

One set of potato tubers which were inoculated with only pathogen (no treatment) served as inoculated control. Other set of tubers inoculated and treated with antibiotic (streptomycin@150ppm) were kept as positive control. Five potato tubers constituted 1 replication and total of 5 replications were maintained in each treatment. The tubers were kept in sterile air tight plastic bags and were stored at $30 \pm 1^{\circ} \mathrm{C}$. Observations on soft rot incidence and severity were recorded on $2^{\text {nd }}$, $4^{\text {th }}$ and $6^{\text {th }}$ day of incubation.

Number of tubers infected Incidence of soft rot disease $=--------\times 100$ Total number of tubers assessed

\section{Tuber rot severity}

Severity of the disease was calculated using 05 scale Bdliya and Langerfeld (2005)

$0 \quad$ No symptoms of rot

$1 \quad 1-15 \%$ tuber rot

$2 \quad 16-30 \%$ tuber rot

$3 \quad 31-45 \%$ tuber rot

$4 \quad 46-60 \%$ tuber rot

$5 \geq 61 \%$ tuber rot

The severity was calculated using formula:

Tuber rot severity $=\frac{\sum \mathrm{nv} \times 100}{------}$

Where, 
$\sum=$ Summation

$\mathrm{v}=$ Disease score

$\mathrm{n}=$ Number of tubers showing a particular score.

$\mathrm{N}=$ Number of tubers examined.

$\mathrm{G}=$ Highest score .

\section{Data analysis}

The collected data was subjected to the analysis of variance using CRD (Complete Randomised Design) and transformed values of the data compared using critical difference (CD) at 5\% level of significance using Statistical Package for Agricultural Research workers (OPSTAT).

\section{Results and Discussion}

\section{The causal pathogen}

The bacterium isolated from potato tubers was a short rod measuring $0.7-1.0 \mu \mathrm{m}$ in width, 1$2.5 \mu \mathrm{m}$ in length, Gram negative, facultative anaerobic, produced acid from D lactose, trehalose and maltose, did not hydrolyze the starch, reduced nitrates, liquefied gelatin, degraded pectin, produced $\mathrm{H}_{2} \mathrm{~S}$ from cysteine, was catalase positive, oxidase negative, urease negative, not sensitive to erythromycin and showed positive growth at $37^{\circ} \mathrm{C}$. Based on Morpho-cultural, biochemical and pathogenic characters, the pathogen was identified as Erwinia carotovora. It was also identified as Erwinia carotovora by ITCC (Indian Type Culture Collection, IARI, New Delhi as per their communication dated: 04/05/2017 bearing receipt No: DD/RF/2016-17/108.

Laboratory evaluation of aqueous plant extracts against the growth of Erwinia carotovora in-vitro

Among the aqueous plant extracts tested against Erwinia carotovora, leaf extract of Datura stramonium showed highest diameter zone of inhibition of $11.7 \mathrm{~mm}$ followed by Ficuscarica, with a zone of $9.5 \mathrm{~mm}$ and other extracts with decreasing order of efficacy were Polygonum hydropiper (leaves), Populus alba (leaves), Trigonella foenum-graecum, Azadirachta indica (leaves), Curcuma longa (Rhizome) and Salix alba (green bark). Cannabis sativa (leaves), Zingiber officinale (rhizome), Juglans regia (leaves) and Conyza Canadensis (leaves) showed moderate efficacy against the test bacterium and least zone of inhibition was exhibited by Anthemis cotula (leaves). Standard check (streptomycin @ 150ppm) gave mean diameter zone of inhibition of $15.3 \mathrm{~mm}$ (Fig. 3).

We have not come across any previous report particularly concerning the efficacy of aqueous plant extracts of Datura stramonium (leaves), Ficus carica, Polygonum hydropiper (leaves), Populus alba (leaves), Trigonella foenum-graecum (seed),Salix alba (green bark), Cannabis sativa (leaves) Juglans regia(leaves and Conyza Canadensis against Erwinia carotovora the causal pathogen of soft rot of vegetables. Growth inhibition of Erwinia carotovora by aqueous extracts of Curcuma longa and Azadirachta indica (leaves) has been previously reported by (Akbar et al., 2014; Opara and Agugo, 2014).

Present study revealed that aqueous plant extracts of Datura stramonium and Ficuscarica are having highest efficacy in inhibiting the growth of Erwinia carotovora. Populus alba (leaves), Trigonella foenumgraecum (seed), Azadirachta indica (leaves), Curcuma longa (Rhizome) and Salix alba (green bark)also gave a satisfactory inhibition against the test pathogen, while as moderate to low inhibition was obtained by Cannabis sativa (leaves), Zingiber officinale (rhizome), Juglans regia (leaves) Conyza canadensis (leaves) and Anthemis cotula. Thus out of aqueous extracts of 13 plants tested, 9 plant species from temperate ecology are being 
probably reported for the first time against Erwinia carotovora, Although amongst them most aqueous extracts have been proven effective against other bacterial species pathogenic to animals. Gachande and Khillare (2013) reported that aqueous extracts of Datura leaves (Datura stramonium) was effective against Gram negative bacteria like Escherichia coli. Further, they reported that leaf extracts of Datura stramonium possess better antimicrobial properties than stem and root. Antibacterial activity of Datura stramonium was also reported by Iranbakhsh et al., (2010). Hydrophilic leaf extracts of Juglans regia, bark of Salix albawasfound effective against E. coli, Staphylococcus aureus, Listeria monocytogenes, Bacillus cereus and Salmonella enteritis (Pop et al., 2013; Shah et al., 2013). Growth inhibition by aqueous extracts of Ficus carica, Polygonum hydropiper (leaves), Populus alba (leaves), Trigonella foenum-graecum (seed), Cannabis sativa (leaves) and Conyza canadensis have been reported against wide range of bacteria viz. E.coli, Micrococcus, Pseudomonas aeruginosa, Bacillus subtilis, Staphylococcus aureus, Klebsiella pneumoniae, Shigella,
Mycobacterium smegmatis, and Mycobacterium aurum. (Al Askari et al., 2013; Haouat et al., 2013; Das et al., 2012; Ayaz et al., 2016; Monika et al., 2014). Gull et al., (2012) reported that bacteria like E. coli, Pseudomonas aeruginosa, Bacillus subtilis, Staphylococcus aureus, Klebsiella pneumoniae, Shigella showed poor susceptibility to the aqueous extract of ginger (Zingiber officinale).

Effect of aqueous plant extracts on incidence and severity of soft rot disease caused by Erwinia carotovora on stored potato tubers

Among 13 plants tested in-vitro against the growth of Erwinia carotovora, three plant extracts showing highest efficacy with respect to growth inhibition are selected for this experiment. Best results were obtained when treatments were given 12 hours prior to inoculation or simultaneously with the inoculation of the pathogen than when treatments were given 12 hours after the inoculation of the pathogen (Fig. 1 and 4).

List of plants and their parts used are as under

\begin{tabular}{|l|c|}
\hline Plant species & Parts used \\
\hline Datura stramonium & Leaves \\
\hline Ficuscarica & Leaves \\
\hline Polygonum hydropiper & Leaves \\
\hline Populus alba & Leaves \\
\hline Trigonella foenum-graecum & Seeds \\
\hline Curcuma longa & Rhizome \\
\hline Azadirachta indica & Leaves \\
\hline Salix alba & Green Bark \\
\hline Cannabis sativa & Leaves \\
\hline Zingiber officinale & Rhizome \\
\hline Juglans regia & Leaves \\
\hline Conyza Canadensis & Leaves \\
\hline Anthemis cotula & Leaves \\
\hline
\end{tabular}


Fig.1 Pathogenicity test by potato slice method

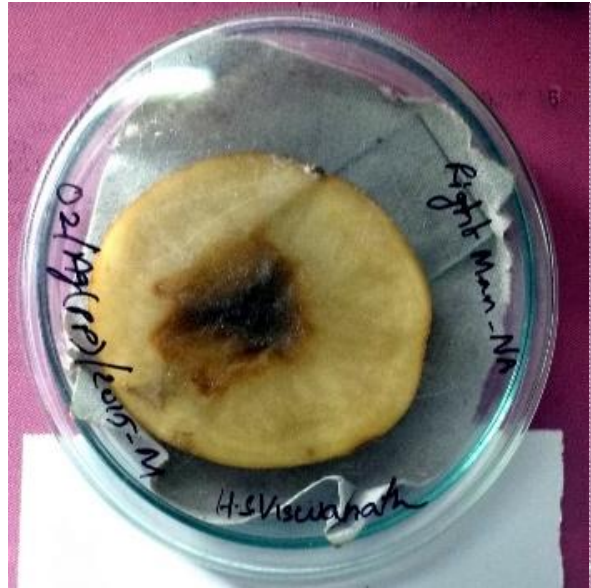

a)

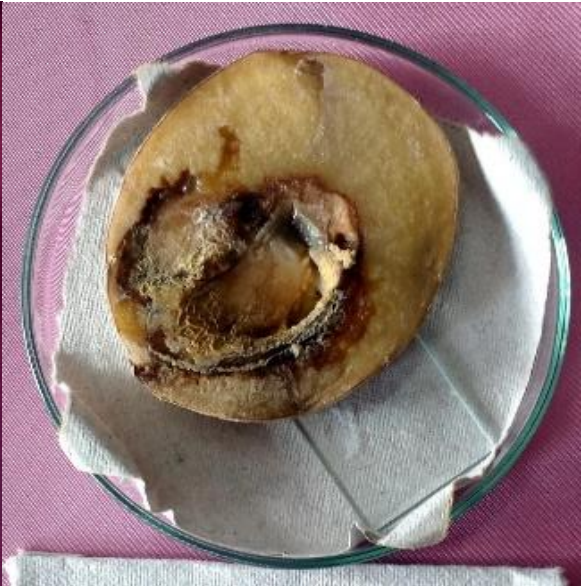

b)

a) Soft rot symptoms after 15 hours of inoculation

b) Symptoms after 3 days after inoculation.

Fig.2 Effect of aqueous plant extracts on the growth of Erwinia carotovora in-vitro by disc diffusion method

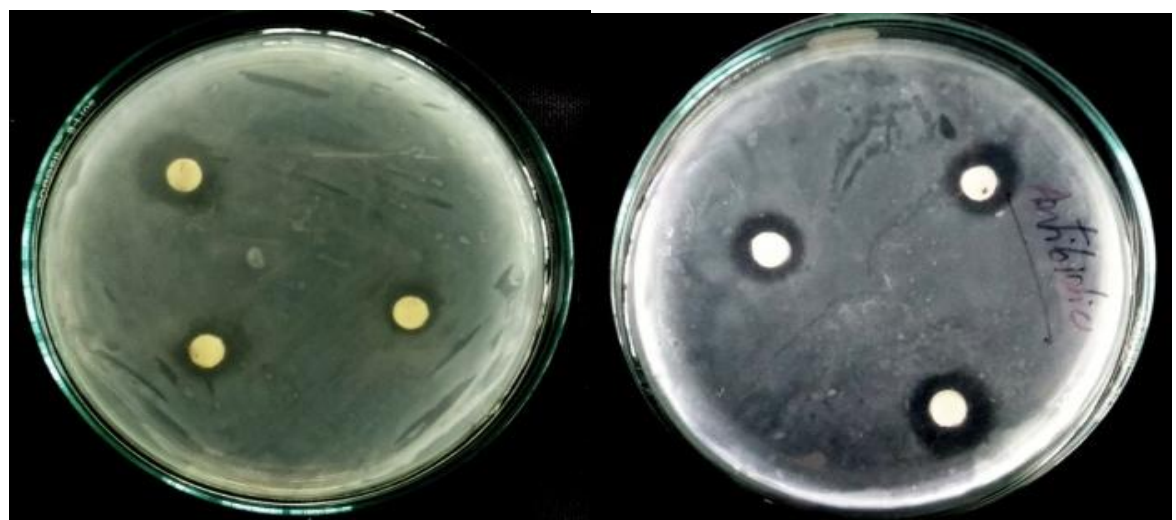

a) Leaf extract of Datura stramonium

b) Streptomycin@150ppm

Fig.3 Effect of plant extracts on the growth of Erwinia carotovora in-vitro

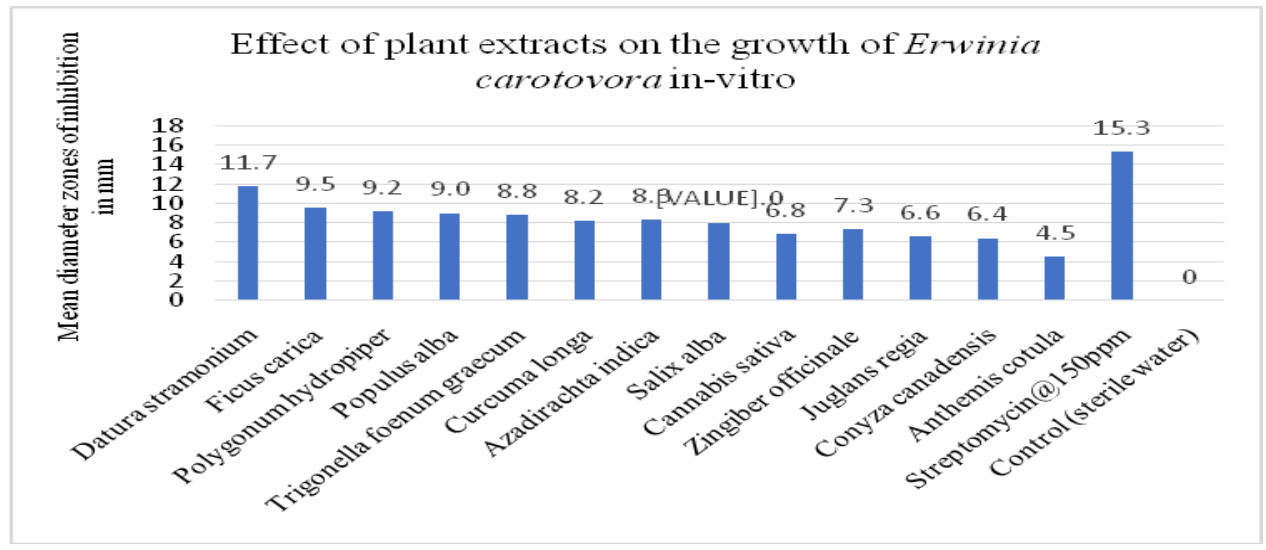


Fig.4 Treatment of aqueous plant extracts on potato tubers after 2 days of storage

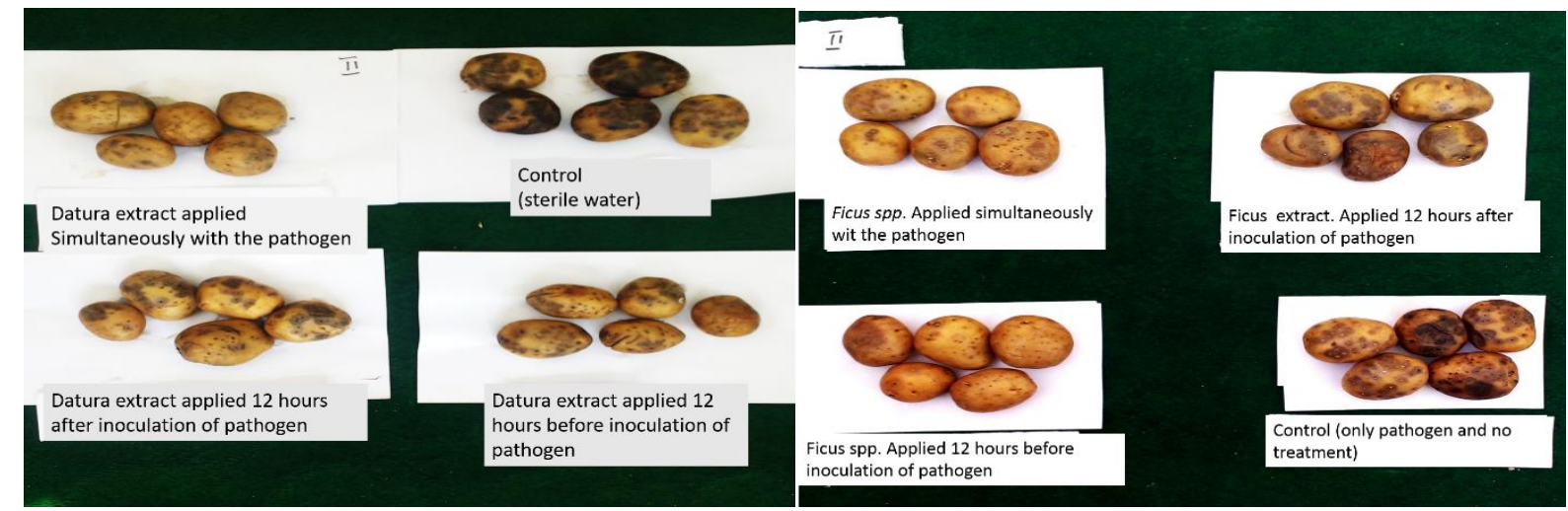

a) Treament with Datura stramonium

b) Treatment with Ficuscarica

Fig.5 Effect of aqueous plant extracts on stored potato tubers after 2 days of storage

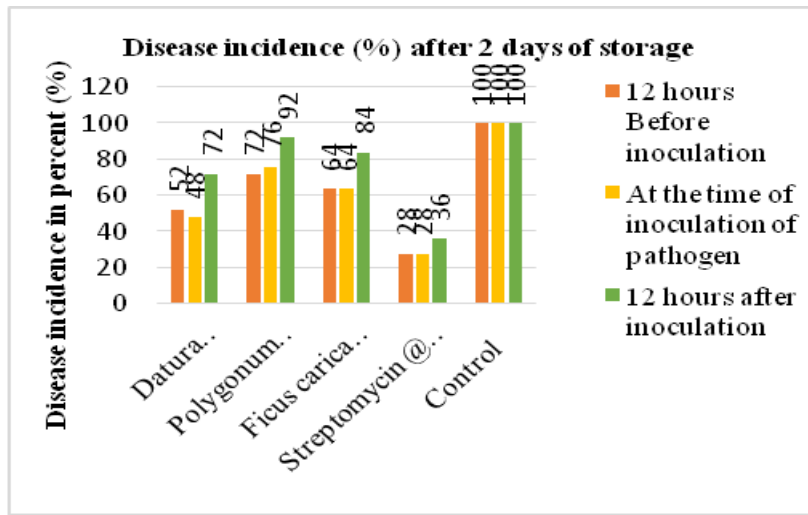

a)

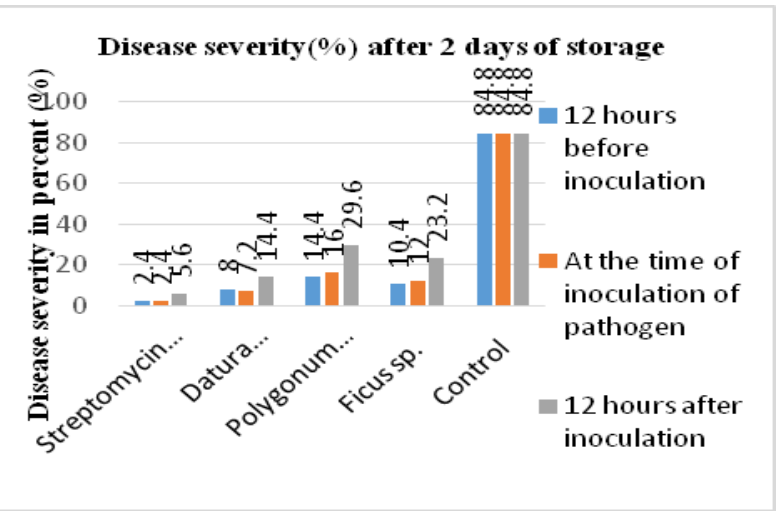

b)

a) Disease incidence after 2 days of storage

b) Disease severity after 2 days of storage

Fig.6 Effect of aqueous plant extracts on stored potato tubers after 4 days of storage

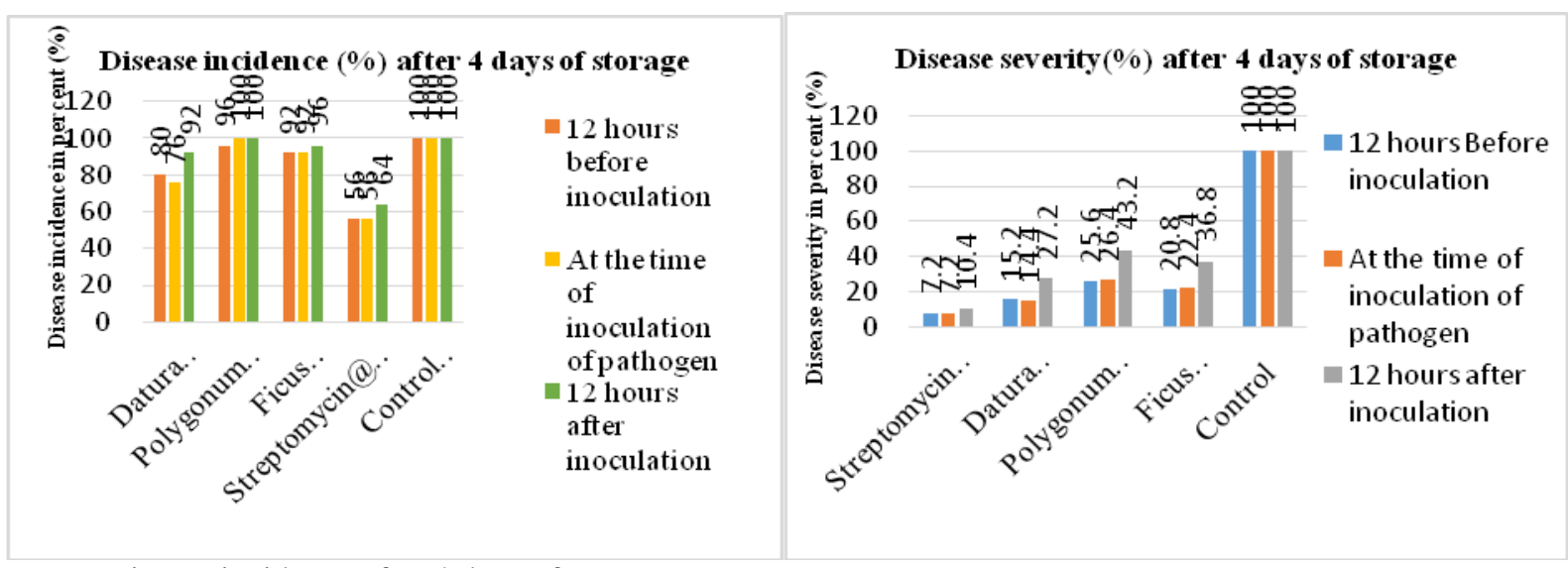

a) Disease incidence after 4 days of storage

b) Disease severity after 4 days of storage 
Fig.7 Effect of aqueous plant extracts on stored potato tubers after 6 days of storage

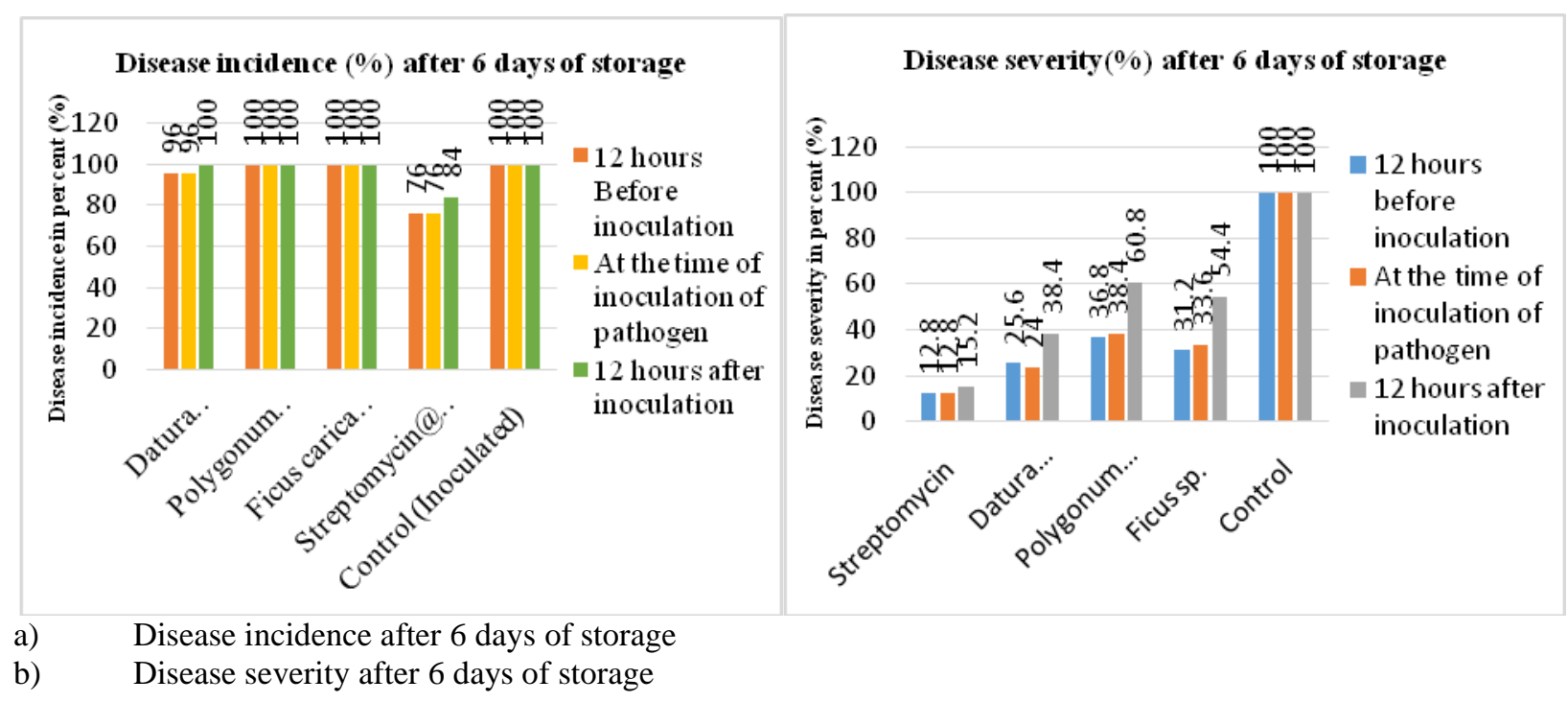

Results obtained after 2 days of storage exhibited that Datura stramonium gave least soft rot incidence of $52 \%$ and $48 \%$ and severity of $8 \%$ and $8.8 \%$ when applied 12 hours prior to and simultaneously with the inoculation of the pathogen respectively, followed by Ficuscarica with $64 \%$ disease incidence and severity of $10.4 \%$ and $12 \%$, respectively. Polygonum hydropiper was recorded next to the above plants in efficacy with incidence of $72 \%$ and $76 \%$ and severities of $14.4 \%$ and $16 \%$ when applied 12 hours prior to and simultaneously with the inoculation of the pathogen. Disease Incidence and severity recorded in case of these extracts was significantly less than that of the inoculated control (pathogen only and no treatment), which showed $100 \%$ soft rot incidence and $84.8 \%$ disease severity. Results are in Figure 5(a,b).

After 4 days of storage, there was a rapid progression of disease in case of inoculated control. Disease progression was less in case of treatments. Least disease incidence of $80 \%$ and $76 \%$ and severity of $15.2 \%$ and $14.4 \%$ respectively, were recorded in case of treatment with Datura stramonium, when applied 12 hours prior to and simultaneously with the inoculation of the pathogen, followed by Ficuscarica with incidence of $92 \%$ incidence in both cases and severity of $20.8 \%$ and $22.4 \%$ when applied 12 hours prior to pathogen inoculation or simultaneously with it, respectively, whereas in Polygonum hydropiper incidence of $96 \%$ and $100 \%$ and severity of $25.6 \%$ and $26.4 \%$ were recorded when applied 12 hours prior to and simultaneously respectively. Whereas in the inoculated control disease severity of $100 \%$ was recorded (Figure 6a, b).

Results obtained after 6 days of storage almost revealed the same trend. Positive check streptomycin showed incidence of $76 \%$ when applied 12 hours prior to or simultaneously with the inoculation of the pathogen even after 6 days of storage. There was no hike in the severity of the disease in case of tubers treated with plant extracts. Treatments with plant extracts protected the tubers from speedy spoilage thereby significantly reducing the severity of disease even after 6 days of storage. Datura stramonium stands best in preventing the severity of disease by exhibiting least severity of $25.6 \%$, when applied 12 hours before inoculation and $24 \%$ when applied 
simultaneously with the inoculation of the pathogen, followed by Ficuscarica with severities of $31.2 \%$ and $33.6 \%$ respectively, when applied 12 hours prior to and simultaneously with the inoculation of the pathogen. Whereas, Polygonum hydropiper was next to the above plant extracts in efficacy exhibiting severities of $36.8 \%$ and $38.4 \%$ when applied prior to and simultaneously with the pathogen respectively. All these extracts were highly significant and superior to the inoculated control (only pathogen and no treatment Figure 7 (a, b).

A thorough search of literature could not reveal any reports regarding control of soft rot caused by Erwinia carotovora in particular by aqueous extracts of Datura stramonium, Ficuscarica and Polygonum hydropiper. However efficacy of aqueous extracts of Ficus sp. against other rot causing bacteria like Pseudomonas, Klebsiella, E. coli, Streptomyces aureus has already been reported by Oyelana et al., (2011), which was in consonance with our results. However, during the course of present study, aqueous extracts of Datura stramonium was also found more effective in decreasing the incidence and severity of post-harvest soft rot caused by Erwinia carotovora up to one week of storage. Hence this study proved the potential of plant extracts of Datura stramonium, Ficuscarica and Polygonum hydropiper for their antimicrobial activity and possibility of developing their use against post-harvest soft rot of vegetables in future which are eco-friendly in nature.

\section{References}

Agrios, G.N. 2007. Bacterial Soft Rots. 5th Edn., Academic Press, San Diego. Pp. 656.

Akbar, A., Din, S., Ahmad, M., Khan, G., and Alam S. 2014. Effect of phytobiocides in controlling soft rot of tomato. Journal of Natural science Research, 4:11.

Al Askari, G., Kahouadji, A., Khedid, K., Ouaffak, L., Mousaddak, M., Charof, R., Mennane, Z. 2013. In vitro antimicrobial activity of aqueous and ethanolic extracts of leaves of Ficuscarica collected from five different regions of Morocco. Journal of Material and Environmental science, 4(1):33-38.

Ayaz, M., Junaid, M., Ullah, F., Sadiq, A., Ovais, M., Ahmad, W. and Zeb, A. 2016. Chemical profiling, antimicrobial and insecticidal evaluations of Polygonum hydropiper L. BMC complementary and alternative medicine, 16(1):502.

Bdliya, B.S., and Langerfeld, E. 2005. Soft rot and Blackleg [Erwinia carotovora ssp. atroseptica (Van Hall) Dye] of potato as affected by inoculum density and variety. Nigerian Journal of Plant Protection, 22:65-75.

Bhat, K.A., Masood, S.D., Bhat, N.A., Bhat, M.A., Razvi, S.M., Mir, M.R., Sabina, A., Wani, N, and Habib, M. 2010. Current status of post-harvest soft rot in vegetables: a review. Asian $\mathrm{J}$. Pl. Sci. 9:200-208

Czajkowski, R., Perombelon, M.C.M., Van veen, J. A., and Van der wolf, J. M. 2011. Control of blackleg and tuber soft rot of potato caused by Pectobacterium and Dickeya species: a review. PlantPathology, 10: 1365-3059.

Das, S., Anjeza, C., and Mandal, S., 2012. Synergistic or additive antimicrobial activities of Indian spice and herbal extracts against pathogenic, probiotic and food-spoiler micro-organisms. International Food Research Journal, 19(3): 1185-1191.

Gachande, B.D., and Khillare, E.M., 2013. Invitro evaluation of Datura species for 
potential antimicrobial activity. Bioscience Discovery, 4(1):78-81.

Gull, I., Saeed, M., Shaukat, H., Aslam, S.M., Samra, Z.Q., and Athar, A.M., 2012. Inhibitory effect of Allium sativum and Zingiber officinale extracts on clinically important drug resistant pathogenic bacteria. Annals of clinical microbiology and antimicrobials, 11(1):8.

Haouat, A.C., El Guendouzi, S., Haggoud, A., David, S., Sqalli, H., Ibnsouda, S., and Iraqui, M. 2013. Antimycobacterial activity of Populusalba leaf extracts. Journal of Medicinal Plants Research, 7(16):1015-1021.

Iranbakhsh, A., Ebadi, M., and Bayat, M. 2010. The inhibitory effects of plant methanolic extract of Datura stramonium L. and leaf explant callus against bacteria and fungi. Global Veterinary, 4(2): 149-155.

Las Llagas, M.C.D., Santiago, L., and Ramos, J.D. 2014. Antibacterial activity of crude ethanolic extract and solvent fractions of Ficuspsedopalma Blanco leaves. Asian Pacific Journal of Tropical Disease, 4(5):367-371.

Monika, N.K., Navneet, K., and Mandeep, K. 2014. Antimicrobial analysis of leaves of Cannabis sativa. Journal of Science, 4(2):123-127.

Oyelana, O.A., Durugbo, E.U., Olukanni,
O.D., Ayodele, E.A., Aikulola, Z.O., and Adewole, A. I. 2011. Antimicrobial activity of Ficus leaf extracts on some fungal and bacterial pathogens of Dioscorearotundata from Southwest Nigeria. Journal of Biological sciences, 11: 359-366.

Pop, C., Vodnar, D., Ranga, F., and Socaciu, C. 2013. Comparative Antibacterial Activity of Different Plant Extracts in Relation to their Bioactive Molecules, as Determined by LC-MS Analysis. Bulletin of the University of Agricultural Sciences and Veterinary Medicine Cluj-Napoca. Animal Science \& Biotechnologies, 70(1):86-94.

Shah, T.S., Ganesh, N., and Akthar, S. 2013. Preliminary phytochemical evaluation and antibacterial potential of different leaf extracts of Juglanaregia: A Ubiquitous Dry Fruit from KashmirIndia. International Journal of Pharmaceutical Sciences Review and Research, 19(2): 93-96.

Shashirekha, M.N., Karanth, N.G.K., and Narasimham, P. 1987. "Surface microflora of seed potatoes (Solanum tuberosum L., Kufri Jyoti): Isolation and identification of organisms responsible for spoilage of potatoes grown at Devanahalli", Journal of Food Science and Technology, 24:261-263.

\section{How to cite this article:}

Viswanath, H.S., K.A. Bhat, N.A. Bhat, T.A. Wani and Mohammad Najeeb Mughal. 2018. Antibacterial Efficacy of Aqueous Plant Extracts against Storage Soft Rot of Potato Caused by Erwinia carotovora. Int.J.Curr.Microbiol.App.Sci. 7(01): 2630-2639. doi: https://doi.org/10.20546/ijcmas.2018.701.314 